\title{
IMPLEMENTASI PEMBELAJARAN MULTIMODEL BERBASIS PENDEKATAN KONTEKSTUAL UNTUK MENINGKATKAN PENCAPAIAN KOMPETENSI DASAR FISIKA DI SLTP
}

\author{
Haratua Tiur Maria \\ Prodi Pend. Fisika Jurusan PMIPA Universitas Tanjungpura Pontianak
}

\begin{abstract}
The aim of this research is to increase the concepts understanding and the student's competences to measure through the application of contextual teaching and learning models. The subject of this research was abut 40 the first level student's of SLTPN 1 Pontianak. The typed of this research was Classrom Action Research (CAR) by two cycles. The aim of the cycle was Contextual Teaching and Learning that focused about base units and derived' units. Through this research, it will found the information about comprehension profile and student's competences related to the measurement. The achievement of the claasroom action research's cycles was the mastery learning of $70 \%$ student that can be done the test minimal $65 \%$. In collecting data the measurement test is done writtenly and performance test. The instruments that used in this research are the concepts understanding and performance test, observation guidance and also the field notes. From the research result, it shown that the qualities of students' concept understanding and competences about measurement are increases. The students' concepts understanding can increase from the average $49,25 \%$ to $78,75 \%$, and the students' competence about measurement increase too from the average $42,19 \%$ to $77,81 \%$. The result study that analyzed by Mc'Nemar test is showing the differences significantly between the result of pretest and posttest to conceptual understanding. Therefore, in general, the application of contextual teaching and learning multimodel can increase the the students' result study significantly.
\end{abstract}

\section{Key word : Multimodel Teaching, Competences, The Contextual Aproach.}

Rendahnya kualitas hasil pembelajaran terutama pada bidang studi eksakta seperti Fisika merupakan salah satu masalah yang dihadapi dunia pendidikan di Indonesia. Sejumlah faktor dianggap sebagai penyebab, diantaranya minat dan perhatian pelajar yang rendah dalam pembelajaran karena menganggap pelajarannya sebagai sesuatu kejadian yang terisolir dari pengalaman hidupnya (Tasker ;1981, dalam Osborne \& Wittrock, 1983).

\begin{abstract}
Hal ini sejalan dengan hasil studi Direktorat Dikmenum yang menyimpulkan bahwa pembelajaran di sekolah cenderung text book oriented dan tidak terkait dengan kehidupan sehari-hari, akibatnya motivasi belajar anak sulit ditumbuhkan dan pola belajar mereka cenderung menghafal dan mekanistik (Blazely,1997). Oleh karena itu, usaha untuk meningkatkan hasil belajar fisika sangat perlu dilakukan. Hasil rangkuman metaanalisis
\end{abstract}


penelitian menemukan bahwa penggunaan metoda mengajar yang tidak konvensional mampu meningkatkan $21 \%$ hasil belajar siswa. Hal ini memberikan gagasan perlunya melakukan suatu pendekatan kepada guru untuk merancang dan mencobakan suatu alternative pembelajaran dengan menerapkan model pembelajaran yang berlandaskan pendekatan kontekstual dalam pembelajaran fisika di SLTP.

Penerapan pembelajaran dengan pendekatan kontekstual atau Contextual Teaching and Learning (CTL) pertama-tama diusulkan oleh John Dewey (Blanchard,2001) yang pada tahun 1916 mengusulkan suatu kurikulum dan metodologi pengajaran yang dikaitkan dengan minat dan pengalaman

Pembelajaran pembelajar. memungkinkan siswa dapat menerapkan pengetahuan dan keterampilan akademik mereka dalam berbagai macam tatanan dalam sekolah dan luar sekolah agar dapat memecahkan masalah-masalah dunia nyata atau masalah-masalah yang disimulasikan (University of Washington, 2001).

Pendekatan kontekstual adalah suatu system yang holistic yang dapat meningkatkan kemampuan pembelajar dalam membangun makna yang dipelajarinya. Tujuh elemen yang menjadi unsur kunci pendekatan kontekstual yaitu ialah Inkuiri, bertanya, Konstruktivisme, masyarakat belajar, penilaian autentik, refleksi dan pemodelan ( The Washington State Consortium for Contextual Teaching and Learning,2001 dalam Widodo,2002). Disamping itu terdapat beberapa komponen lain yaitu pembelajaran bermakna, penerapan pengetahuan, menyediakan lingkungan yang mendukung pembelajaran mandiri, adanya kolaborasi, Berpikir kritis dan kreatif, responsive terhadap budaya serta menggunakan penilaian autentik (Johnson,2002).

Landasan berpikir pendekatan kontekstual adalah Konstruktivisme yang memandang bahwa belajar adalah proses aktif seseorang dalam membangun pengetahuan yang bermakna dalam dirinya sendiri melalui interaksi dengan lingkungannya, dengan cara membangun keterkaitan antara pengetahuan yang dimilikinya dengan yang sedang dipelajarinya (Driver, et al, dalam Osborne \& Wittrock; Sutrisno, 1998)

Penerapan multimodel merupakan gabungan dari beberapa model yang diterapkan dengan pendekatan kontekstual. Salah satu model pembelajaran yang dapat diterapkan dengan pendekatan kontekstual adalahmodel Pengajaran Langsung (Direct Instruction/DI).Model ini berdasar teori belajar sosial yang dikembangkan oleh Albert Bandura, yang berpandangan bahwa belajar yang dialami manusia sebagian besar diperoleh dari suatu pemodelan yaitu meniru perilaku dan pengalaman orang lain. Pengajaran langsung merupakan model yang tepat dalam mengembangkan belajar siswa tentang pengetahuan deklaratif dan pengetahuan prosedural (Nur,2000). Pada sintaks model pengajaran langsung terdapat lima fase pembelajaran yaitu : (1) menyampaikan tujuan dan mempersiapkan siswa; (2) mendemonstrasikan pengetahuan atau 
keterampilan; (3) membimbing pelatihan; (4) mengecek pemahaman dan memberikan umpan balik; serta (5) memberikan kesempatan untuk pelatihan lanjutan dan penerapan.

Model pembelajaran lain yang dapat diterapkan dengan pendekatan kontekstual adalah

model pembelajaran kooperatif (Cooperative Learning/CL). Model ini dikembangkan berdasarkan teori belajar kognitif-konstruktivis tentang hakikat sosiokultural dari pembelajaran oleh Vygotsky (Sudibyo,2002). Pembelajaran kooperatif merupakan suatu model pembelajaran dimana siswa belajar dalam kelompok-kelompok kecil yang memiliki tingkat kemampuan berbeda, dan siswa saling bekeija sama dan membantu untuk memahami bahan pembelajaran dalam menyelesaikan tugas kelompok. Model ini sangat tepat dilaksanakan untuk mengembangkan keterampilan sosial siswa dan dalam memahami konsep-konsep yang sulit.

Adapun sintaks model pembelajaran kooperatif adalah adanya 6 fase pembelajaran yaitu: (1) menyampaikan tujuan dan memotivasi siswa; (2) menyajikan informasi; (3) mengorganisasikan siswa ke dalam kelompok-kelompok belajar; (4) membimbing kelompok bekeija dan belajar; (5) evaluasi; dan (6) memberikan penghargaan.

Model pembelajaran lain ialah model Pengajaran berdasarkan masalah (Problem based Instruction/PBI) yang menyajikan kepada siswa suatu situasi masalah yang autentik dan bermakna untuk memberi kemudahan bagi siswa melakukan penyelidikan dan inkuiri (Sudibyo,2002). Pembelajaran ini bertujuan untuk mengembangkan kemampuan berpikir, pemecahan masalah dan keterampilan intelektual siswa.

Terdapat lima fase dalam sintaks model pengajaran berdasarkan masalah, yaitu : (1) Orientasi siswa kepada masalah; mengorganisasikan siswa untuk belajar; (3) membimbing penyelidikan individu maupun kelompok; (4) mengembangkan dan menyajikan hasil karya; serta (5) menganalisis dan mengevaluasi proses pemecahan masalah.

Model pembelajaran berikutnya adalah model pembelajaran generatif (Generative learning), yang dikembangkan oleh Osborne \& Wittrock (1985) berdasarkan teori konstruktivisme dan teori belajar generative (1983). Intisari dari belajar generatif adalah bahwa otak tidak menerima informasi dengan pasif, melainkan justru dengan aktif mengkonstruk suatu interpretasi dari informasi tersebut dan kemudian membuat kesimpulan. Jadi otak bukanlah suatu 'blank slate' yang dengan pasif belajar dan mencatat informasi yang datang (Wittrock, 1974, 1980, dalam Osborne \& Wittrock, 1983). Sintaks model pembelajaran generatif terdiri dari lima fase yaitu : (1) Fase Orientasi yaitu memotivasi siswa dengan mengkaitkan materi dengan pengalaman siswa sehari-hari; (2) Pengungkapan Ide, yaitu untuk mengetahui konsepsi awal siswa; (3)Tantangan dan Restrukturisasi, yaitu untuk menciptakan terjadinya konflik kognitif dalam diri siswa; (4) Penerapan, untuk memberikan kesempatan kepada siswa menerapkan konsep yang 
dipelajarinya dalam menyelesaikan masalah; dan (5) Melihat kembali, yaitu memberi kesempatan siswa membandingkan konsepsinya yang lama dan yang telah dipelajarinya untuk melihat keunggulan konsep ilmuwan.

\section{METODE PENELITIAN}

Jenis penelitian yang dilakukan adalah penelitian tindakan kelas. Penelitian dilakukan secara kolaborasi oleh tim peneliti dengan guru fisika di SLTP. Penelitian dilakukan di SLTP Negeri di Pontianak dengan mengambil salah satu kelas untuk menjadi subjek penelitian. Penelitian ini terdiri dari 2 siklus, dimana setiap siklus mengikuti alur kegiatan mengikuti konsepsi Kemmis dan Mc Taggart tentang penelitian tindakan kelas (Arends,2000) yang terdiri dari perencanaan, tindakan, observasi dan refleksi.

Adapun sasaran pembelajaran yang ingin dicapai setiap siklus adalah sebagai berikut:

- Siklus 1 : pembelajaran dengan pendekatan kontekstual yang memfokuskan pada pengukuran besaran pokok.

- Siklus 2 : pembelajaran dengan pendekatan kontekstual yang memfokuskan pada pengukuran besaran turunan.

Tingkat keberhasilan untuk setiap siklus adalah bila minimal $70 \%$ siswa mampu menjawab dengan benar paling tidak $65 \%$ dari soal yang ada.

\section{HASIL DAN PEMBAHASAN}

Pelaksanaan tindakan dalam penelitian ini dilakukan dalam dua siklus, yaitu siklus ke-I menekankan pada pemahaman konsep pengukuran dan siklus ke-2 menekankan pada kompetensi melakukan pengukuran.

Berdasarkan analisa hasil pretes tentang kualitas pemahaman konsep siswa pada materi pengukuran ditemukan bahwa secara umum hasil pretes masih tergolong rendah, yaitu rata-rata skor yang dicapai adalah 4,925 dari skor maksimum 10 atau 49,25 \%. Adapun skor terendah adalah 2 dan skor tertinggi adalah 8 . Ini menunjukkan bahwasebelum pembelajaran konsepsi awal siswa ada yang telah sesuai dengan konsepsi ilmuwan dan sebagian belum sesuai dengan konsepsi ilmuwan. Kesulitan menyelesaikan soal umumnya dialami siswa tentang pengukuran baku serta perhitungan satuan dan besaran.

Tes untuk mengetahui konsepsi siswa tentang pengukuran setelah pembelajaran dilakukan pada akhir siklus tindakan. Rata-rata hasil postes dari 40 siswa adalah 7,875 dengan skor tertinggi 10 dan skor terendah 6 dari skor maksimum 10 . Jadi terdapat peningkatan rata-rata skor sebesar 2,95 dari hasil tes awal siswa yang menunjukkan terjadi peningkatan pemahaman konsepsi siswa tentang pengukuran.

Dari analisis terhadap jawaban siswa dalam menyelesaikan soal postes, secara umum dapat diketahui bahwa sebagian besar jawaban siswa sudah sesuai dengan konsep ilmiah yaitu lebih dari $90 \%$ siswa menjawab benar paling tidak $65 \%$. Berdasarkan hasil ini ketuntasan belajar minimal $70 \%$ siswa menjawab benar $65 \%$ telah tercapai. Mean dari data pretes dan postes tentang konsepsi pengukuran siswa dapat digambarkan dalam bentuk grafik (gambar 1). 


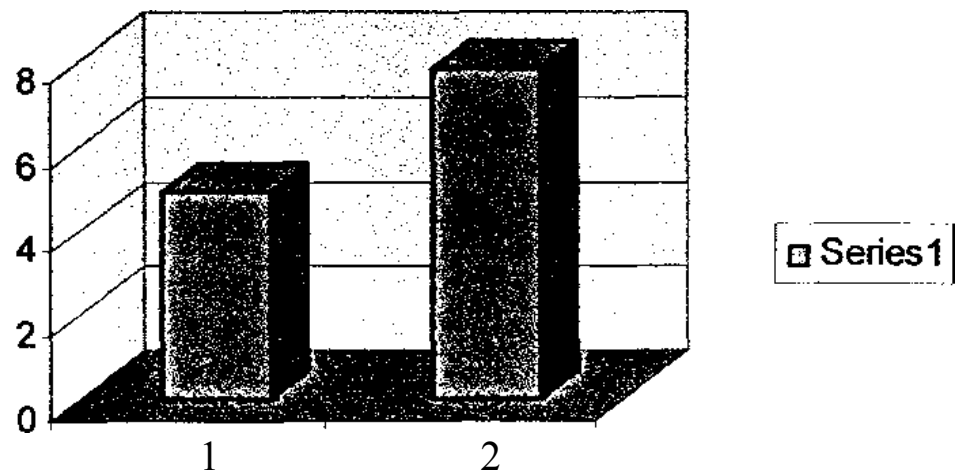

Gambar 1. Rekapitulasi Konsepsi Siswa tentang Pengukuran

Keterangan: 1. Mean Skor Pretes 2. Mean Skor Postes

Dilihat secara numerik dari data hasil tes siswa dan analisis terhadap jawaban siswa dalam menyelesaikan soal postes, secara umum dapat diketahui bahwa pembelajaran dengan pendekatan kontekstual dapat meningkatkan skor pemahaman siswa tentang pengukuran. Peningkatan pemahaman konsep siswa tentang pengukuran dianalisis dengan uji statistik signifikansi perubahan Mc'Nemar.

Pada taraf signifikansi $\alpha=5 \%$ dan $\mathrm{dk}=1$, hasil perhitungan enunjukkan bahwa dari 10 soal yang diujikan terjadi peningkatan pemahaman konsep siswa pada 9 soal atau sebesar $90 \%$. Pada soal nomor 8 tidak teijadi peningkatan hasil dari pretes ke postes secara signifikan.

Tes untuk mengetahui kompetensi siswa melakukan pengukuran setelah pembelajaran dilakukan pada akhir siklus tindakan. Selain untuk mendapatkan data tentang kemampuan siswa melakukan unjuk kerja tentang materi yang disampaikan, tes juga bertujuan untuk mengetahui ketercapaian tujuan tindakan yang dilakukan pada siklus tindakan yaitu adanya ketuntasan belajar bila minimal $70 \%$ siswa mampu menjawab tes dengan benar paling tidak $65 \%$ dari soal yang diberikan.

Kompetensi siswa melakukan pengukuran diketahui dari tes kinerja yang diberikan siswa sebelum dan sesudah pembelajaran. Soal tes terdiri dari 4 buah soal uraian yang meminta siswa mekukan pengukuran langsung dengan menggunakan alat ukur dan meminta siswa menjelaskan langkah dalam melakukan pengukuran. Ratarata hasil postes dari 40 siswa adalah 12,45 dengan skor tertinggi 16 dan skorterendah 9 dari skor maksimum 16. Jadi terdapat peningkatan rata-rata skor sebesar 5,7 dari hasil tes awal siswa. Mean dari data pretes dan postes tentang kompetensi siswa melakukan pengukuran dapat digambarkan dalam bentuk gambar 2 . 


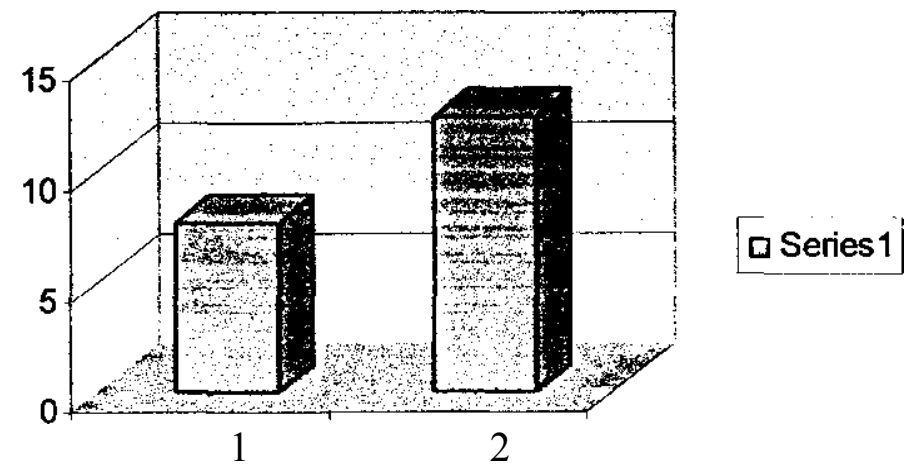

Gambar 2. Rekapitulasi Kompetensi Siswa

Keterangan: 1. Mean Skor Pretes 2. Mean Skor Postes

Berikut ini akan diuraikan tindakan dan pembahasan hasil penelitian pada masing- masing siklus. Pada siklus 1, pembelajaran difokuskan pada konsep pengukuran dan konsep besaran dan satuan. Pembelajaran pada siklus ini dilaksanakan 2(dua) kali pertemuan.

Pada pertemuan pertama, pembelajaran dilaksanakan dengan model pengajaran Langsung (Direct Instruction) dan Model Pembelajaran Kooperatif. Adapun materi pokok adalah Pengukuran dengan topik Pengukuran Baku \& Tak Baku serta Pengukuran Panjang. Pembelajaran diawali dengan meminta dua siswa mengukur panjang meja guru dengan menggunakan jengkal, dimana yang dipilih adalah siswa yang besar dan kecil dan membandingkan hasilnya dengan pengukuran panjang meja guru tersebut dengan menggunakan mistar untuk pengukuran baku dan tak baku.

Pengajaran langsung tampak dari pemodelan oleh guru cara penggunaan mistar dan jangka sorong yang baik dan benar. Kegiatan percobaan menggunakan alat ukur panjang oleh siswa dilakukan secara kelompok oleh siswa dengan bimbingan guru. Kesulitan yang tampak dalam pembelajaran ini adalah waktu yang dibutuhkan oleh siswa dalam menggunakan jangka sorong agak lama karena umumnya siswa belum pernah menggunakan alat ini. Siswa terlihat aktif dan bersemangat dalam kegiatan percobaan dan mempresentasikan hasil kerja kelompoknya.

Pertemuan kedua membahas tentang pengukuran massa dan waktu. Pembelajaran dilakukan dengan menggunakan gabungan pembelajaran Generatif dan Pengajaran Langsung. Kegiatan inti dilakukan dengan pemodelan cara menggunakan neraca O'Hauss untuk mengukur massa dan menggunakan stopwatch untuk mengukur waktu.

Pada siklus II, pembelajaran difokuskan pada pengukuran Volume dan Massa jenis benda. Pada pertemuan pertama, pembelajaran dilaksanakan dengan model pengajaran Langsung (Direct Instruction) dan Model PembelajaranGeneratif. Adapun materi pokok adalah Pengukuran dengan topik Pengukuran Volume 
benda, baik benda beraturan maupun benda tak beraturan.

Pada kegiatan inti dalam pertemuan pertama ini, pengajaran langsung tampak dari pemodelan oleh guru cara mengukur volume benda beraturan yaitu kubus kayu serta mengukur volume benda tak beraturan yaitu batu yang dibawa anak dengan menggunakan gelas ukur. Dari pengamatan yang dilakukan tampak bahwa pembelajaran ini dapat menarik perhatian siswa untuk aktif. Kesulitan yang tampak dalam pembelajaran ini adalah konversi satuan dan perhitungan volume benda.

Pertemuan kedua membahas tentang pengukuran massa jenis benda. Pembelajaran dilakukan dengan menggunakan gabungan pembelajaran Generatif dan Pembelajaran Kooperatif. Kegiatan awal dilakukan dengan meminta beberapa siswa mengukur secara kualitatif dan membandingkan mana yang lebih besar volumenya antara kubus tembaga dan kubus kayu yang sama ukuran sisinya. Pada umumnya siswa berpendapat bahwa volume kubus tembaga lebih besar dari kubus kayu, walaupun mereka telah mengetahui rumus volume benda beraturan.

Pada kegiatan menyelesaikan LKS 4 tentang Massa Jenis, siswa terlihat aktif dan antusias dalam melakukan keija kelompok dengan bimbingan guru. Berdasarkan analisa hasil keija kelompok siswa dalam melakukan percobaan dan menyelesaikan Lembar Kegiatan Siswa (LKS), terlihat bahwa sebagian siswa mengalami kesulitan dalam mengkonversi satuan volume sehingga perlu tambahan penjelasan oleh guru tentang konversi satuan yang berpangkat 3 (tiga).

Berdasarkan hasil postes
ditemukan bahwa
pemahaman konsep siswa tentang pengukuran meningkat. Hal ini terlihat dari hasil uji statistik yang dilakukan, bahwa pemahaman konsep siswa meningkat secara signifikan, kecuali pada soal nomor 8 yang menuntut kemampuan siswa mampu menyelesaikan masalah konversi satuan dan perhitungan. Kesalahan umumnya teijadi pada konversi satuan hasil perhitungan volum serta ketelitian siswa dalam melakukan perhitungan. Karena kriteria ketuntasan bahwa lebih dari $70 \%$ siswa dapat menjawab benar minimal $65 \%$ dari keseluruhan soal, maka tindakan untuk pembelajaran pengukuran dianggap sudah selesai.

Hasil wawancara dengan beberapa siswa tentang proses pembelajaran mengungkapkan bahwa siswa merasa senang dalam belajar, karena proses pembelajaran menarik dan juga karena adanya kegiatan melakukan percobaan. Beberapa siswa lain juga mengemukakan bahwa mereka merasa puas dan bangga karena diberi kesempatan mempresentasikan hasil kerja kelompoknya serta pemberian applaus dari teman sebagai pemberian penghargaan bagi siswa yang menyelesaikan penyajiannya.

Melalui observasi pelaksanaan pembelajaran dan hasil diskusi dengan guru di tempat penelitian, terlihat bahwa pembelajaran dengan pendekatan kontekstual dapat memotivasi siswa untuk memberikan perhatiannya serta terlibat aktif dalam tiap tahapan pembelajaran. Kedua hal ini menurut, Osborne \& Wittrock 
(1983) merupakan hal yang penting dalam menentukan keberhasilan belajar siswa. Hal ini juga sesuai dengan hasil penelitian Ramidi (1994, dalam katu,1995), bahwa siswa sering merasa tidak senang terhadap pelajaran fisika disebabkan karena cara pengajaran fisika yang langsung mengadakan pembahasan materi tanpa menarik perhatian siswa, dan jarang melakukan percobaan ataupun demonstrasi serta tidak pernah memberikan contoh yang konkret (kontekstual).

Adapun model pembelajaran yang dianggap dapat meningkatkan pencapaian tujuan pembelajaran adalah pembelajaran yang menggabungkan beberapa model yang ada, yang dikenal sebagai pembelajaran multimodel. Pembelajaran ini bisa gabungan antara pengajaran langsung dengan pembelajaran generatif, ataupun pembelajaran generatif dengan pembelajaran kooperatif seperti yang dilakukan dalam penelitian. Pengajaran langsung dianggap berkontribusi sangat baik bagi keterampilan siswa menggunakan alat karena memberi kesempatan siswa meniru pemodelan yang dilakukan oleh guru. Tahap-tahap pada pembelajaran generatif ataupun pembelajaran kooperatif memberi kesempatan siswa aktif dalam membangun pengetahuannya melalui kegiatan yang menarik.

Adapun kesulitan yang dialami dalam penerapan pembelajaran ini adalah terbatasnya alat dan sarana pembelajaran yang tersedia di kelas, sehingga beberapa alat yang ada dipakai secara bergantian oleh beberapa kelompok.

\section{Kesimpulan dan Saran}

Berdasarkan hasil analisa data dan pembahasan dapat dikemukakan kesimpulan penelitian sebagai berikut;

1. Pada umumnya konsepsi awal siswa tentang pengukuran masih belum sesuai dengan konsep ilmiah yaitu rata-rata dari 40 orang siswa adalah 4,925 dari skor maksimum 10 dengan skor terendah 2 dan skor tertinggi 8 .

2. Kualitas kompetensi awal siswa melakukan pengukuran masih rendah yaitu rata- rata dari 40 orang siswa adalah 6,75 dari skor maksimum 16 dengan skor terendah 5 dan skor tertinggi 11.

3. Secara umum pembelajaran kontekstual dapat meningkatkan pemahaman siswa tentang konsep pengukuran, hal ini terlihat dari rata-rata skor dari 40 orang siswa setelah pembelajaran meningkat menjadi 7,875 dari skor maksimum 10 dengan skor terendah 6 dan skor tertinggi 10. Peningkatan pemahaman konsep siswa secara signifikan terlihat terjadi hampir pada semua soal yang diberikan, kecuali pada soal nomor 8 , dimana siswa banyak yang mengalami kesulitan dalam konversi satuan dan perhitungan volume.

4. Kompetensi siswa melakukan pengukuran setelah pembelajaran meningkat 
menjadi rata-rata 12,45 dari skor maksimum 16 dengan skor terendah 9 dan skor tertinggi 16.

5. Model berlandaskan kontekstual pembelajaran pendekatan dapat meningkatkan pemahaman dan kompetensi siswa melakukan pengukuran, karena dalam penerapannya dapat memotivasi siswa untuk memberikan perhatiannya serta terlibat aktif dalam kegiatan pembelajaran. Adapun kesulitan yang dialami dalam penerapan pembelajaran ini adalah adanya topik yang memerlukan waktu yang lebih banyak dari yang direncanakan.

Adapun strategi pembelajaran yang dianggap dapat meningkatkan pencapaian kompetensi dasar siswa tentang pengukuran adalah dengan menerapkan pembelajaran dengan pendekatan kontekstual dan menggabungkan beberapa model pembelajaran yang ada atau disebut pembelajaran multimodel.

Berdasarkan hasil analisis data penelitian dan kegiatan penelitian yang telah dilakukan, maka dapat disarankan hal berikut:

1. Karena pembelajaran multimodel dengan pendekatan kontekstual dapat meningkatkan pemahaman dan kompetensi siswa, maka diharapkan para guru fisika SLTP mengembangkannya sebagai alternatif dalam pembelajaran di sekolah, terutama dalam pembelajaran topik yang penyajian konsepnya dapat dilakukan dengan percobaan yang sederhana dan berkaitan dengan hidup sehari- hari.

2. Penggabungan model pembelajaran atau multimodel dilakukan dengan menyesuaikan dengan karakteristik materi yang akan disajikan.

\section{Daftar Pustaka}

Anwar.(2004), Pendidikan Kecakapan Hidup. Bandung:Alfabeta.

Black,P. \& Atkin,J.M. (Eds)(1996), Innovations in Science, Mathematics and Technology Education, London:Routledge. Dahar,R.W. (1996), Teori-Teori Belajar, Jakarta : Erlangga.

Depdiknas, (2002), Model Pembelajaran, Jakarta: Depdiknas

Driver,R. \& Idham,V., (1986), A Constructivist Approach to Curriculum Development in Science, Studies in Science Education, 13, 105-106.

Giancoli,D.C., 1991, Physics Principles with Applications, third ed., USA : Prentice- Hall International.

Ibrahim,M,(2000), Pembelajaran Kooperatif, Surabaya, Unesa University Press.

Johnson, B. Elaine, (2002), Contextual Teaching and Learning, USA, Corwin Press, Inc 
Klausmeier, H.J, (1980), Learning and Teaching Concepts, Wisconsin : Academic Press.

Katu, N., (1995), Pengajaran Fisika yang Menarik, Salatiga: Universitas Satyawacana.

Novak, D.J, (1977), A Theory of Education, New York : Cornell University Press.

Nur,M,( 2000), Strategi-Strategi Belajar, Surabaya, Unesa University Press

Osborne,R.I. \& Wittrock, M.C., 1983, Learning in Science: A Generative Process, Science Education, 67 (4), 489-508.

Anonim. (1985), The generative Learning Model and Its Implications for Science

Education, Studies in Science Education, 12, 59-89.

Siegel, S., (1992), Statistik Nonparametrik, Jakarta: PT Gramedia Pustaka Utama.

Sutrisno, L., (1991), Konsep Awai Siswa dan tradisi konstruktivis, Universitas Tanjungpura Pontianak, Tidak Diterbitkan .

Anonim, (1993), Implementasi Tradisi Constructivisit dalam Pendidikan di Indonesia, Universitas Tanjungpura Pontianak, Tidak Diterbitkan.

Anonim, (1998),Reformasi Bidang Pendidikan di Indonesia: Revolusi Berpikir,Sumbang Saran Kepada Menteri Pendidikan dan Kebudayaan, Tidak Diterbitkan.

Sudibyo, E, (2002), Beberapa Model Pengajaran dan Strategi Belajar dalam Pembelajaran IPA-Fisika, Surabaya, Unesa

Usman dan Setiawati, (1993), Upaya Optimalisasi Kegiatan Belajar
Mengajar, Bandung: Remaja Rosdakarya

University of Washington College of Education, 2002, Indonesian Teaching Training Project, The Washington State Consortium For ContextuaI Teaching and Learning

Van den Berg,E,(1991),Miskonsepsi Fisika dan Remediasi, Yogyakarta:UKSW.

Wittrock, M.C, (1994), "Generative Science Teaching"' Dalam The Content of Science: A Constructivist Approach to Its Teaching and Learning,London: The Falmer Press.

Wahono Widodo, (2002), Pengajaran dan Pembelajaran Kontekstual, Surabaya, Unesa. 